\title{
Anomalous high origin of right coronary artery above the sinotubular junction: rarely diagnosed anomaly
}

\author{
Devender Singh, Anshuman Darbari, Manish Kumar Sharma, Nirav Parikh \\ CTVS, Wockhardt Hospital, Surat, India
}

Correspondence to Anshuman Darbari, darbarianshu@indiatimes.com

\section{DESCRIPTION}

A 28-year-old man was admitted with clinical signs of severe aortic regurgitation with left ventricular hypertrophy, which was later confirmed by ECG, transthoracic and transoesophageal echocardiography. There was no evidence of vegetations on any valves, root abscess, fistulas, myocardial abscess or purulent pericarditis. Coronary angiography was not contemplated in view of young age. The patient was taken up for aortic valve replacement surgery under general anaesthesia after proper investigations.

After midline sternotomy, we found dilated right coronary artery (RCA) originating anomalously high from the ascending aorta (figure 1). On aortotomy, right coronary ostium was not found at the normal place in the right coronary sinus but the RCA origin was abnormally high and above the sinotubular junction (displaced vertically and laterally). Tricuspid calcified aortic valve was excised and replaced by a mechanical prosthetic valve. Aortotomy incision was closed carefully in two layers taking care to avoid being close to the dilated RCA origin (figure 2). Post cardiopulmonary bypass recovery was smooth. There was no evidence of ischaemia in the right coronary territory. He was discharged on the seventh day.

Coronary artery anomalies result from disorders that take place during the third week of fetal development. ${ }^{1}$ Coronary anomalies are classified as significant or major, which are those that cause myocardial perfusion disorders, and non-significant or minor, which are those in which the coronary flow is normal. Significant anomalies have a low incidence and account for $0.25-0.9 \%$ of congenital heart diseases. For this reason, alterations in the coronary flow caused by these anomalies and their clinical significance remain unknown. ${ }^{23}$

As described, this anomaly is of no haemodynamic significance but creates problems during engagement of an angiographic catheter, ${ }^{3}$ but this is a rare finding during operation.

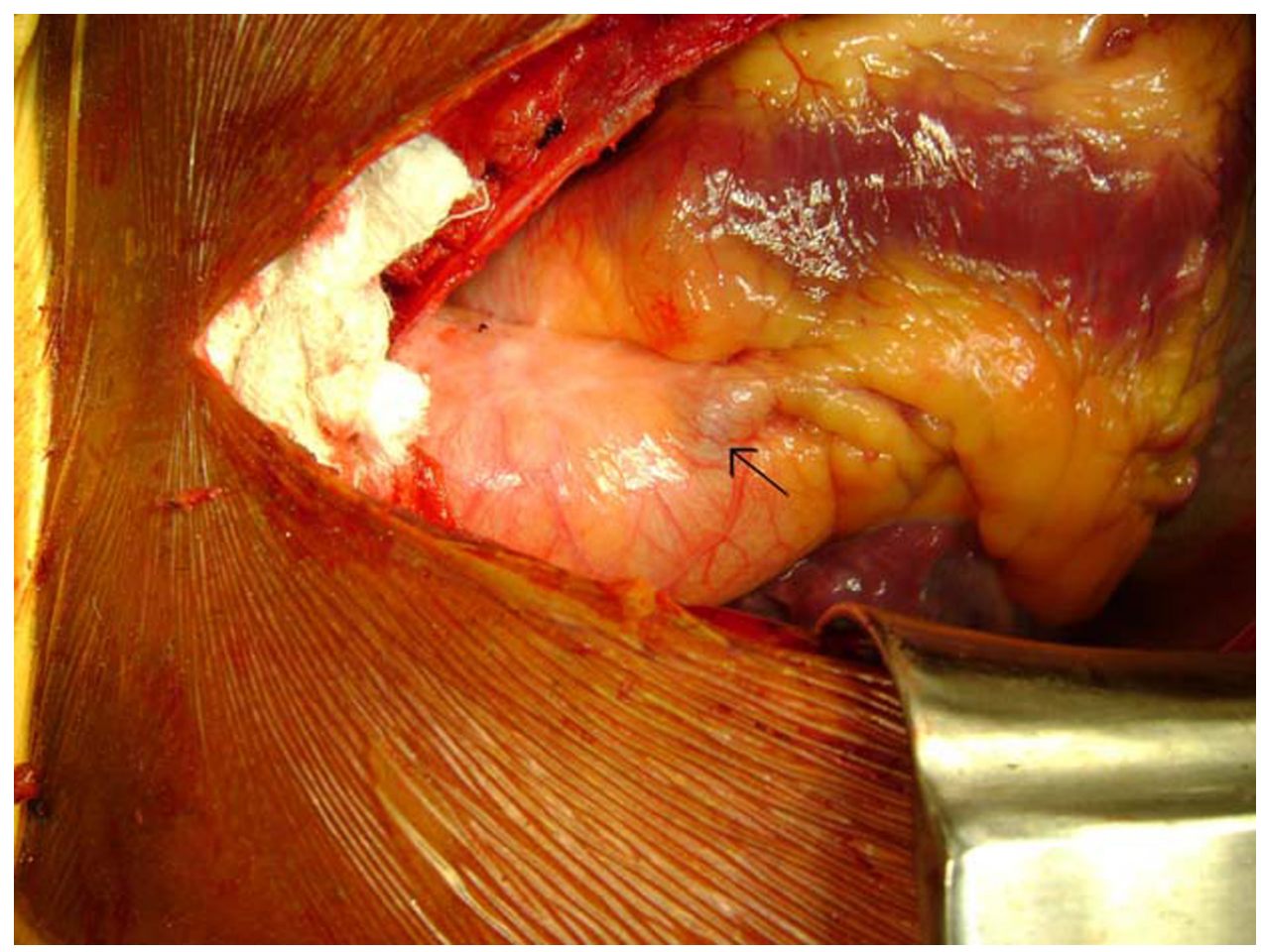

Figure 1 Anomalous high origin of dilated right coronary artery (marked by arrow) above the sinotubular junction on the ascending aorta (photograph taken from the right-hand side of patient). 


\section{BMJ Case Reports}

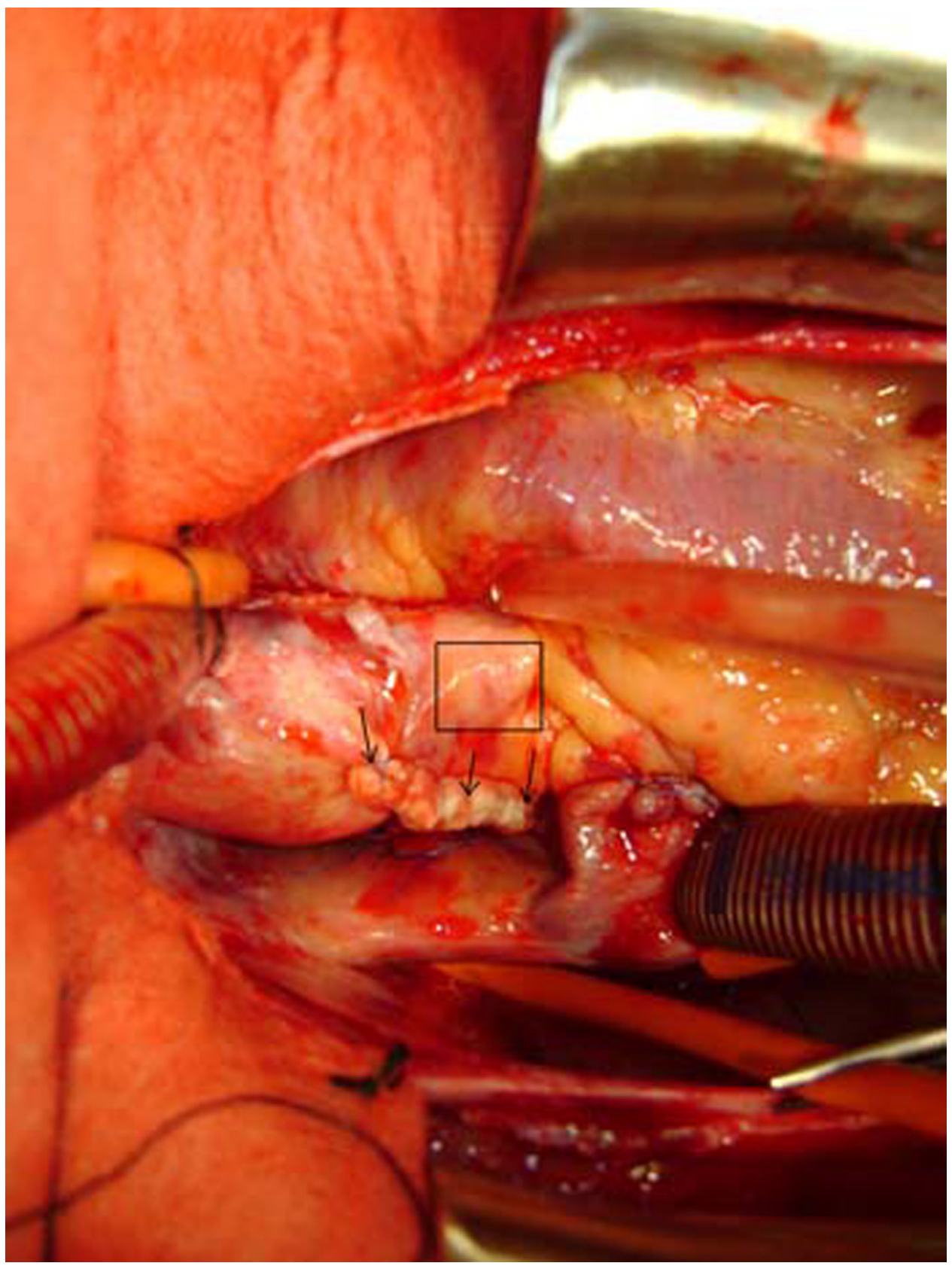

Figure 2 Photograph taken after closure of aortotomy; the box area indicates anomalous right coronary artery origin and the arrows point to the suture line away from the anomalous origin of the right coronary artery (photograph taken from the head end side of patient).

\section{Competing interests None}

Patient consent Obtained.

\section{REFERENCES}

1. Angelini P. Coronary artery anomalies: an entity in search of an identity. Circulation 2007;115:1296-305.
2. Angelini P. Coronary artery anomalies-current clinical issues: definitions, classification, incidence, clinical relevance, and treatment guidelines. Tex Heart Inst J 2002;29:271-8.

3. Popma JJ. Coronary arteriography and intravascular imaging. In: Libby $\mathrm{P}$, Bonow RO, Mann DL, Zipes DP, Braunwalds E, eds. Braunwald's Heart disease: A Text Book of Cardiovascular Medicine. Philadelphia, PA: Elsevier 2008:488. 


\section{BMJ Case Reports}

This pdf has been created automatically from the final edited text and images.

Copyright 2010 BMJ Publishing Group. All rights reserved. For permission to reuse any of this content visit http://group.bmj.com/group/rights-licensing/permissions. BMJ Case Report Fellows may re-use this article for personal use and teaching without any further permission.

Please cite this article as follows (you will need to access the article online to obtain the date of publication).

Singh D, Darbari A, Sharma MK, Parikh N. Anomalous high origin of right coronary artery above the sinotubular junction: rarely diagnosed anomaly. BMJ Case Reports 2010;10.1136/bcr.12.2009.2537, date of publication

Become a Fellow of BMJ Case Reports today and you can:

- Submit as many cases as you like

Enjoy fast sympathetic peer review and rapid publication of accepted articles

- Access all the published articles

Re-use any of the published material for personal use and teaching without further permission

For information on Institutional Fellowships contact consortiasales@bmjgroup.com

Visit casereports.bmj.com for more articles like this and to become a Fellow 